\title{
Closing the Mental Health Gap: The Long and Winding Road?
}

\author{
Mary Bartram \\ Carleton University \\ Steve Lurie \\ Canadian Mental Health Association
}

\begin{abstract}
With 5 billion dollars in new federal funding to improve access to mental health services set to roll out over the next 10 years, a window of opportunity has opened to begin to close the long-standing gap in mental health funding in Canada. Public spending on mental health in Canada is only $7 \%$ of public spending on health overall (Jacobs et al., 2010), well short of the 9\% called for in the Changing Directions, Changing Lives: The Mental Health Strategy for Canada (MHCC, 2012). This percentage is also well short of the disease burden comprised by mental illnesses, which ranges from $13 \%$ globally (WHO, 2011) to $23 \%$ in the UK (OECD , 2014). By comparison, recent figures from the Organisation for Economic Cooperation and Development (OECD, 2014) indicate that some countries devote as much as $18 \%$ of their health spending to mental health, with the UK sitting at $13 \%$. Even with new targeted federal funding, closing, or at least narrowing, this gap will require careful attention to lessons learned in the past. This article explores how the gap in mental health funding came about in Canada and provides a more detailed analysis of the size of the gap itself. While it is now clear that the federal government will introduce a transfer that is directly targeted to mental health, there are still many policy options to consider for moving forward with next steps, including provincial/territorial contributions, accountability mechanisms, outcome measures, the insurance/financing model, and how tightly eligible expenses are tied to specific initiatives, population groups, or levels of evidence.
\end{abstract}

Key words: mental health spending, funding, policy, Canada

\section{RÉSUMÉ}

Les nouveaux fonds fédéraux de 5 milliards de dollars qui seront investis au cours des 10 prochaines années pour améliorer l'accès aux services de santé mentale sont une excellente occasion de commencer à combler l'écart qui existe depuis longtemps en matière de financement des soins de santé mentale au Canada. Les dépenses publiques dans ce domaine ne représentent en effet que $7 \%$ de l'ensemble des dépenses

Mary Bartram, School of Public Policy and Administration, Carleton University, Ottawa, Ontario; Steve Lurie, CMHA, Toronto Branch, Toronto, Ontario, and Inwentash Faculty of Social Work, University of Toronto, Toronto, Ontario.

Correspondence concerning this article should be addressed to Mary Bartram, c/o School of Public Policy and Administration, Room 5224, River Building, Carleton University, 1125 Colonel By Drive, Ottawa, Ontario, Canada K1S 5B6. Email: mary.bartram@carleton.ca 
publiques consacrées à la santé (Jacobs et al., 2010), ce qui est beaucoup moins que les $9 \%$ recommandés dans Changer les orientations, changer des vies - Stratégie en matière de santé mentale pour le Canada (MHCC, 2012). C'est aussi très loin de ce que constitue le fardeau des maladies, dont l'évaluation va de $13 \%$ (dans le monde) (WHO, 2011) à $23 \%$ (au Royaume uni) (OECD, 2014). En comparaison, de récentes données de l'OCDE (OECD, 2014) montrent que certains pays consacrent jusqu'à $18 \%$ de leurs dépenses en santé à la santé mentale - ce chiffre étant de $13 \%$ au Royaume-Uni. Même avec les nouveaux fonds fédéraux ciblés, il faudra, si nous voulons combler - ou, à tout le moins, rétrécir l'écart -, bien tenir compte des leçons que nous pouvons tirer du passé. Dans cet article, les auteurs expliquent comment cet écart dans le financement des services de santé mentale s'est créé au Canada, et font une analyse détaillée de la taille de cet écart. Alors qu'il est maintenant clair que le gouvernement fédéral fera un transfert qui sera spécifiquement consacré aux services de santé mentale, nous devons considérer plusieurs options, en matière de politiques, si nous voulons aller de l'avant et franchir avec succès les prochaines étapes : la définition de la contribution des provinces et des territoires, la mise en place de mécanismes d'imputabilité, l'évaluation des résultats, la création d'un modèle d'assurance/financement et la définition des dépenses admissibles en lien avec des projets donnés, des groupes de population ou des niveaux de données probantes.

Mots clés : dépenses en santé mentale, financement, politiques publiques, Canada.

With five billion dollars in new federal funding to improve access to mental health services set to roll out over the next 10 years, a window of opportunity has opened to begin to close the long-standing gap in mental health funding in Canada. To date, public spending on mental health in Canada has only been 7\% of public spending on health overall (Jacobs et al., 2010), well short of the $9 \%$ called for in the Changing Directions, Changing Lives: The Mental Health Strategy for Canada (MHCC, 2012). This percentage is also well short of the disease burden comprised by mental illnesses, which ranges from 13\% globally (WHO, $2011)$ to $23 \%$ in the UK (OECD, 2014). By comparison, recent figures from the Organisation for Economic Cooperation and Development (OECD, 2014) indicate that some countries devote as much as $18 \%$ of their health spending to mental health, with the UK sitting at 13\%. To use Ontario as an example, between 2004 and 2011 Ontario made new investments of $\$ 16.45$ per capita in mental health, compared to new investments of \$62.22 per capita in the UK, \$98.13 in Australia, and \$198.93 in New Zealand (in Canadian dollars using 2011 exchange rates; Lurie, 2014). On its own, new federal investment stands to narrow the $\$ 3.1$ billion gap by $\$ 500$ million annually, and add $\$ 13.78$ per capita in new investments.

Even with new federal funding, closing (or at least narrowing) this gap in line with international benchmarks will require careful attention to lessons learned from the past. This paper explores how the gap in mental health funding came about in Canada (using Ontario as an illustrative example) and provides a more detailed analysis of the size of the gap itself. While it is now clear that the federal government will introduce a transfer that is directly targeted to mental health (with a focus on children and youth, improving access to mental health services, and reducing unnecessary hospitalization), there are still many options to consider for moving forward, including provincial/territorial contributions, accountability mechanisms, outcome measures, indicators of success, the insurance/financing model, and how tightly eligible expenses are tied to specific initiatives, population groups, or levels of evidence. 


\section{HISTORICAL OVERVIEW 1837-2014}

The history of mental health policy in Canada has been largely one of exclusion, evasion, and neglect. Mental health has been too stigmatized, too expensive (in light of the sheer numbers of people affected), and too jurisdictionally thorny (particularly in Canada) to be appropriately prioritized (Bartram, 2016). In 1957, the federal government's decision to exclude mental hospitals from public health insurance opened up a gap that has yet to be closed. Without targeted federal transfers backed by an effective accountability mechanism, history tells us that there has been little hope of provincial and territorial governments being able to do so on their own (Bartram, 2016). Even with such transfers, challenges related to stigma, competing fiscal pressures, and jurisdictional politics remain.

Mental health policy in Canada has developed in a highly political, highly complex environment (Bartram, 2016). Not only is the Canadian federal system highly decentralized but health care may be the most politically contested policy arena, resulting in intensely political policy negotiations between federal, provincial, and territorial governments at different points in Canadian history (Ouimet, 2014; Banting \& Corbett, 2002). When stigmatized attitudes regarding mental illness and the sheer numbers of people affected are added to the mix, it is little wonder that in the Canadian context a funding gap emerged and to date has proved so difficult to close.

At the outset, mental illness was a priority for colonial governments. In step with the development of asylums in Europe and the American colonies, the first asylum was established in Saint John in 1837 with others soon to follow. By 1867, asylums were so widespread that they were specifically named as an area of provincial jurisdiction in the Canadian constitution (Canada, 2012). This jurisdictional arrangement carried on until the two world wars opened up a period of centralization in Canada that has not been seen since.

In the post-war period, provincial preoccupations with autonomy were set aside in the face of urgent national priorities, including the mental health needs of returning soldiers. In 1948 the federal government introduced a $\$ 7$ million annual mental health grant, the largest of a suite of grants for priority health issues under the new national health program. With direct federal vetting of provincial proposals, this suite of grants was the first and most federally directed health transfer ever put in place. However, this program was only a first installment on universal health insurance coverage. When the far more significant investment was made in universal hospital insurance with the Hospital Insurance and Diagnostic Services Act (HIDSA) in 1957, mental hospitals were excluded.

As can be seen from the debates in the House of Commons, jurisdiction, stigma, and balking at the cost all played a role. The federal minister of health at the time, Paul Martin, Senior, used the long-standing provincial role in funding asylums as well as the pre-existing federal mental health grant as a rationale: "It would be wrong by any principle ... for us to include as part of the hospital insurance scheme ... mentally ill people who receive treatment in provincial institutions" (Canada, House of Commons, 1957:2677). Further, "This bill is designed to assist individuals in their individual hospital problems and not to subsidize provinces which are receiving assistance in other ways from the government" (Canada, House of Commons 1957:3384).

This position was criticized by opposition parties as discrimination in the face of the significant cost of expanding coverage. For example, Saskatchewan MP Andrew Nicholson argued that: "[I]t is most unfortunate that half of the people who are sick every day in the year are barred from the benefits of this so-called national 
health insurance plan... The cost per day for the patients in the mental hospitals of Canada [was] \$2.70 per patient per day in the mental hospitals ... and $\$ 10.77$ per day in the public hospitals. It now becomes clear why the minister is trying to get [out] from under the responsibility of the federal government for this very large group" (Canada, House of Commons 1957:3382). Leader of the opposition John Diefenbaker put it thus: "Why are these [mental] hospitals ... discriminated against? ... This load of responsibility cannot be discharged properly by the provinces" (Canada, House of Commons 1957:3386).

This debate continued right up until moments before the third reading of the HIDSA, and carried over (in a somewhat more muted fashion) into the debate over insurance for physician services outside of hospitals. The 1968 Medical Services Act upheld the exclusion of mental hospitals from public health insurance in Canada. This decision was justified based on recommendations from the government-appointed Hall Commission to shift mental health care from asylums to general hospitals and communities. This recommendation was itself informed by the 1963 publication More for the Mind, which confirmed the sorry state of mental health services in Canada due to lack of funding and the exclusion of mental health services from public and private medical insurance plans, and called for a shift in service provision from inpatient services to community-based psychiatric services (Lurie \& Goldbloom, 2015). However, the government ignored Hall's recommendations to first expand insurance coverage as part of a phased approach, in recognition of the fact that the 68,000 beds in uninsured mental hospitals comprised nearly half of the hospital beds in Canada at that time (Canada, Royal Commission on Health Services, 1964:24).

This time around, Parliamentary Secretary for Health Margaret Rideout more openly acknowledged the cost and jurisdictional considerations: "The question of extending federal contributions so as to include mental and tuberculosis hospitals is a financial question and is precisely the type of question which is now being studied in depth, along with other federal-provincial financial arrangements, by the tax structure committee" (Canada, House of Commons 1967:1798-9).

In the 1970s and '80s, the federal role in mental health further diminished. With the shift from costshared to block federal health transfers, the federal share of health began its slide from $50 \%$ of total health insurance costs (which continued all the way to down to $9 \%$ in 2001 and back up to $21 \%$ in 2014). In exchange for this reduced federal share, provincial and territorial governments gained increased autonomy over how this money was spent (Ouimet, 2014). In the face of this increasing fiscal pressure, it is not difficult to see how provincial governments could have been drawn down the path of incomplete de-institutionalization. While shifting from institutional- to community-based care was a noble objective, provincial governments closed mental hospital beds without following through with the re-allocation of funds to the community. As argued by MP David Orlikow: "The idea was that [people who had spent years ... in mental hospitals] would be serviced outside in the community... [E]ven in a city like Toronto there are very few services for these people, so they are going back to the hospitals again." (Canada, House of Commons 1982:15869).

The Canada Health Act could have responded to the growing need for broader health insurance with coverage for non-physician health and mental healthcare providers such as nurses and psychologists, but instead only addressed the issue of extra billing. As noted by then Minister of Health Monique Bégin, there was simply no appetite from either level of government to expand coverage into so-called grey areas: "Some ministers felt it put expansionist pressure on the health-care system ... Strategic as well as economic considerations prevented me from deviating one iota from the principle that the basic rules of health insurance 
remain unchanged ...[T]he provinces did not want to see anything in this category [mental illness] included in medicare" (Bégin 1988:160-161).

Mental health received more attention through the health reform years in the 1990s and 2000s, but not enough to make a dent in the funding gap. During this period many provinces developed mental health plans that proposed shifting resources to the community, but major investments in community mental health did not occur. Investments were made in more than 20 mental health pilot projects through federal transition funds that were designed to support transformation in primary health care and broader health systems (Goldner, 2002; Health Canada, 2007), but these mental health investments were ultimately marginal. Mental health was crowded out by competing priorities as was best exemplified by the way mental health was tacked on to homecare in the 2004 Health Accord as "short-term acute community mental health home care for twoweek provision of case management and crisis response services" (Canada, 2004).

In hindsight, it is difficult to see how significant progress could have been made in closing the mental health funding gap in the 1990s and 2000s. Numerous reports calling for investments in mental health (Lurie, 2014) were in direct competition with heightened concern regarding spiralling costs for the health system in general. Without federal transfers that were earmarked for mental health, historical funding patterns that favoured spending on hospitals, physicians, and drugs were further entrenched (Mulvale, Abelson, \& Goering, 2007). What Stuart, Alboreda-Florez, and Sartiorius (2012) have identified as a structural stigma likely played a role as well. Moreover, jurisdictional issues were as thorny as ever over this time period. While the federal health transition funds were managed more like grants, with fairly strong accountability mechanisms such as federal vetting of proposals and project reports, federal efforts to hold provincial and territorial governments to account for Health Accord dollars through the Health Council of Canada ultimately fell flat (Health Council of Canada, 2014).

\section{Ontario as a Case in Point}

The experience in Ontario is a case in point, in terms of both mental health's overall share of health spending and the ratio of spending on community-based to institution-based mental health care. In 1979, 10 years after Ontario reduced psychiatric hospital beds from 11,000 to less than 4,000, the mental health share of health spending was $11.3 \%$. By 1985 this had decreased to $9 \%$ as health care spending increased in other areas (Lurie, 2014). A 1988 analysis done for the Graham Report, Building Community Support for People, showed that mental health spending was continuing to decline as a proportion of health spending, despite a government commitment to double funding for community mental health services (Ontario Ministry of Health, 1988). A subsequent report in 1993, Putting People First, proposed spending targets for a community-focused mental health system (Ontario Ministry of Health, 1993). In response, the government proposed shifting community-based funding from $20 \%$ of the mental health spend to $60 \%$ over a 10 year period, to fundamentally recalibrate the balance of community-based and institutional mental health care. This target has not been met, even though community-based mental health's share of overall health spending has increased from $0.45 \%$ to $1.31 \%$ over the past 25 years (Lurie, 2005).

Ontario did use the earlier Health Accord funds to make significant investments in mental health care. Nevertheless, mental health's share of health spending did not increase as these mental health investments 
were outpaced by investments in other areas of health care. From 2004 to 2011, health spending increased by $\$ 18.5$ billion, but investments in mental health were less than $\$ 500$ million (Lurie, 2014). While Ontario did match the federal funding of $\$ 110$ million (which came from the Health Accord's homecare transfer), far more was invested in other areas of health care during the period. Total new investments for health services over this period were $\$ 1,361$ per capita, but new mental health investments were only $\$ 16.45$ per capita (Lurie, 2014). A recently commissioned report for the Ontario Ministry of Health estimates there is an annual gap between mental health spending and need of \$1.5 billion (McMaster Health Forum, personal communication, 2016). This calculation is close to the $\$ 1.2$ billion amount of funding per year required to bring Ontario's mental health share of health spending to the $9 \%$ target, as will be explained at a national level below.

\section{BREAKING DOWN THE NUMBERS}

Before turning to an analysis of key policy options for next steps in closing the mental health gap, it is important to more closely examine the size of this gap (see Figure 1). As noted at the outset of this paper, a recent OECD report (2014) found that some countries devote as much as $18 \%$ of their health spending to mental health, with the UK sitting at 13\%. In Canada, the most recent analysis found that mental health's share of public spending on health is only 7\% (Jacobs et al., 2010). What would it take to bring this share to $9 \%$ over 10 years, as recommended in The Mental Health Strategy for Canada (MHCC, 2012)? How far does the new federal $\$ 5$ billion over 10 years go toward reaching this target?

\section{Figure 1}

\section{Closing the Mental Health Gap (annual amounts)}

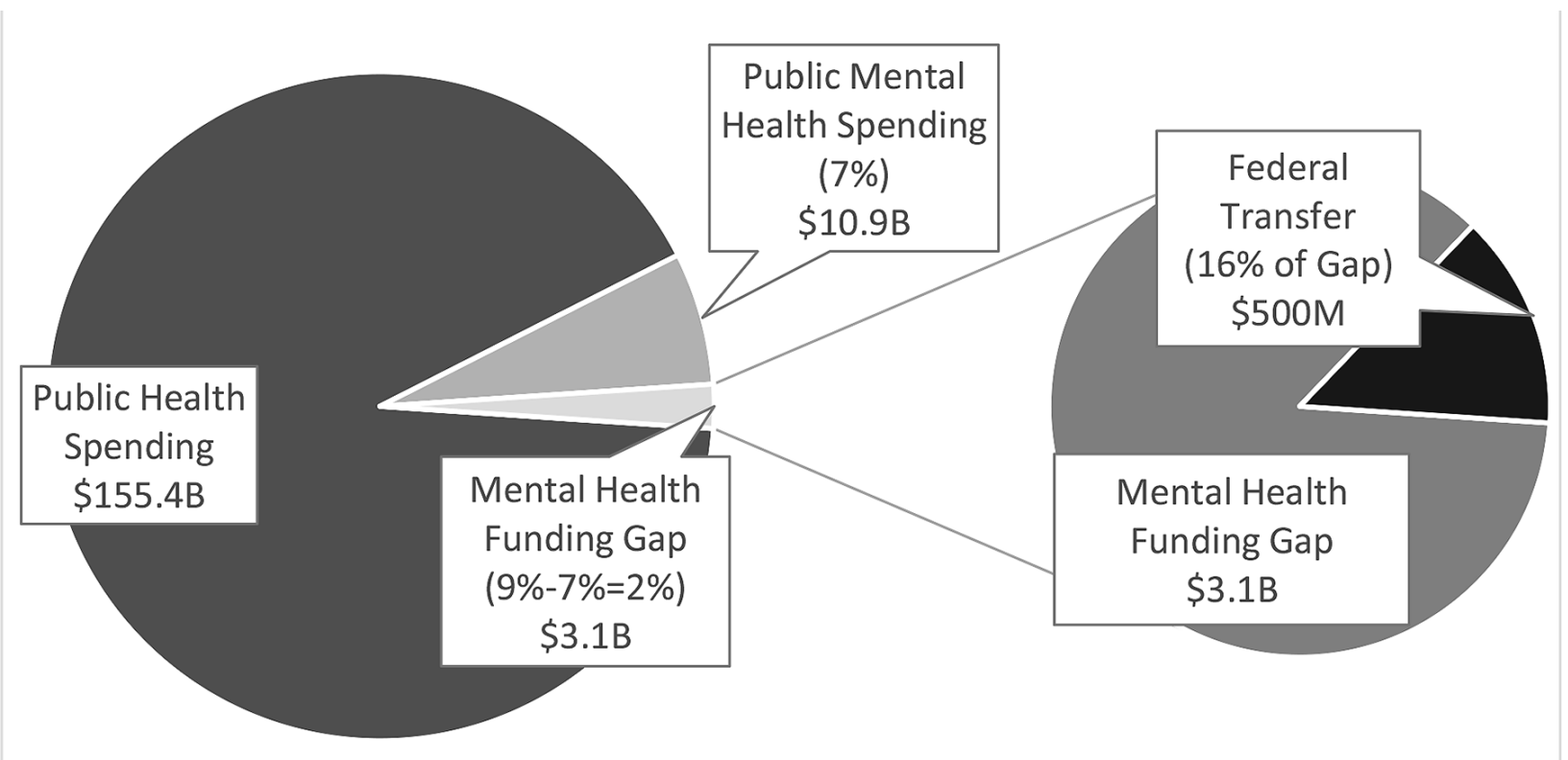


According to the Canadian Institute for Health Information, Canada's health spending in 2015 totalled \$219 billion (CIHI, 2015). This includes spending by both federal and provincial governments. Spending by the private sector accounts for $29 \%$, with public sector spending accounting for $71 \%$ (CIHI, 2015). Since the Health Accord negotiations were focused on government transfers, we do the same here. At $71 \%$, the public share of total health spending in 2015 was $\$ 155.4$ billion, and the mental health share at 7\% was $\$ 10.9$ billion. Increasing the mental health spend from $7 \%$ to $9 \%$ would require an investment of $\$ 3.1$ billion annually, or $\$ 85.43$ per capita. If the target were to be achieved over a 10 year period it would require an incremental base funding increase of $\$ 310$ million each year or $\$ 8.54$ per capita.

These calculations may actually underestimate what is required to close the gap. First, they rest on the unrealistic assumption that spending on other areas of health does not increase. Second, mental health's actual share of health has likely declined below $7 \%$ given the investments in other areas of health spending since 2007/08 when the last analysis was conducted by Jacobs et al. (2010). For example, mental health's current share of health spending in Saskatchewan has been estimated at 5\% and the current figure used for planning in Ontario estimates 6.3\% (Lurie, personal communication, 2016). Third, \$3.1 billion annually is less than the $\$ 4.23$ billion base increase called for by the Canadian Mental Health Association in 2015 (based on total health spending; CMHA, 2015).

The Mental Health Strategy for Canada also called for a two percentage point increase in social spending, in light of the key role that social spending plays in mental health policy (MHCC, 2012). Breaking down the numbers for social spending is more complex. Canada's GDP was estimated to be \$1.78 trillion in 2016 (Statistics Canada, 2016). Canada spends $17.0 \%$ of GDP on social spending, less than the OECD average (OECD, 2016). Accordingly, the social spend figure can be calculated to be $\$ 303$ billion. A $2 \%$ increase in social spending would be $\$ 6$ billion. Spread over 10 years, this would provide scope for activities such as scaling up Housing First and supportive employment initiatives across the country, and reducing homelessness among the 520,000 people living with mental illness across the country who are either homeless or precariously housed (MHCC, 2013).

Taken together, the $\$ 3.1$ billion increase in health spending and the $\$ 6$ billion increase in social spending would total $\$ 9.1$ billion per year, with a per capita cost of \$251 per year or less than $\$ 25$ per capita added to health and social spending each year for 10 years. To put these numbers into perspective, the Canada Health Transfer (CHT) to the provinces and territories went from about $\$ 20$ billion to roughly $\$ 34$ billion between 2005 and 2015 (an increase of $\$ 13.7$ billion) and the Canada Social Transfer (CST) increased from \$8.4 billion to $\$ 12.95$ billion in the same period (an increase of $\$ 4.5$ billion). The total health and social transfer to provinces and territories increased from $\$ 28$ billion to $\$ 46.9$ billion (an increase of $\$ 18.9$ billion). In 2016/17 the combined health and social transfers are estimated to reach $\$ 49.4$ billion (Finance Canada, 2016).

While falling short of $\$ 3.1$ billion annually, the new federal mental health transfer of $\$ 5$ billion over 10 years stands to make a significant contribution to narrowing the health spending gap (see Figure 1). Setting aside the question of ramping up, $\$ 5$ billion over 10 years averages close to $\$ 500$ million annually ( $\$ 13.78$ per capita), or $16 \%$ of the $\$ 3.1$ billion annual gap ( $\$ 13.78$ of the $\$ 85.43$ per capita gap calculated above).

To take Ontario as an example, Ontario's share of the $\$ 5$ billion will be $\$ 1.925$ billion over 10 years, or $\$ 192.5$ million annually on average. As Ontario’s share of the $\$ 3.1$ billion annual gap at the national level 
is $\$ 1.2$ billion, the new federal investments will be just over \$1 billion short of closing the gap. Ontario's stated mental health priorities are psychotherapy, supportive housing, and services for youth (Ontario, 2017). Leaving capital costs aside, it is estimated that the costs of providing supportive housing rent supplements and services to 30,000 people would be $\$ 522$ million (Lurie, personal communication, 2017). If Ontario applied all of its federal mental health transfer funding to only this priority, the province would need to add $\$ 330$ million of its own funds. While this figure represents only $0.6 \%$ of Ontario's current spending on health, the province faces many competing healthcare priorities.

\section{CLOSING THE MENTAL HEALTH GAP: NEXT STEPS}

Thus far, this paper has provided a historical perspective on the challenges related to stigma, jurisdiction, and balking in the face of costs, as well as a detailed analysis of the mental health funding gap and new federal funding commitments. With these considerations front-of-mind, the key challenges and opportunities for the next steps in closing the mental health gap can now be thoughtfully considered.

The current federal Liberal government threw open a window of opportunity by promising to both improve access to mental health services and negotiate a new Health Accord. Upon election in 2015, these promises were reiterated in the mandate letter for federal Minister of Health Jane Philpott (Prime Minister of Canada, 2015). In late 2016, the federal government exercised considerable political will by offering to transfer $\$ 5$ billion over 10 years to support provincial and territorial government efforts to improve access to mental health services. The federal position was backed by high levels of public and stakeholder support, with $90 \%$ of Canadians supporting targeted federal funding for mental health and $83 \%$ identifying improved mental health services as a priority for a new Health Accord (CMHA, 2015; Canadian Medical Association, 2016). Professional associations and stakeholder organizations were also united in calling for targeted federal funding for mental health (Canadian Alliance for Mental Illness and Mental Health, 2016).

However, even with strong public and stakeholder support, and a very significant federal offer on the table, jurisdictional issues threatened to undermine the possibility of meaningful progress during negotiations. Federal Minister of Health Jane Philpott insisted on targeted transfers tied to clear conditions and accountability for results: "There are some real advantages in us actually focusing on some specific areas like home care and investing [money] separately from the transfer...Canadians can see new spending through the federal government's support into health care will actually deliver the kinds of things Canadians want" (Lunn, 2016, June 23). Not surprisingly, Quebec Premier Phillipe Couillard was "totally opposed to targeted funding" on the basis of provincial jurisdiction (Lunn, 2016, June 23). While three Atlantic provinces quickly accepted the federal offer, the remaining provinces and territories continued to hold out for more control and more money. They objected to a an offer with a targeted transfer which fell outside of the more flexible CHT, and with a CHT increase from 3\% to only $3.5 \%$ (Galloway, 2017, January 3). In this sense, advances in mental health were once again at risk of being overshadowed by more pressing healthcare priorities. As argued by Manitoba Premier Brian Pallister, "if the victory of mental health comes at the defeat of everyone else who needs health care outside of that category, that's hardly useful” (Kirkup, 2017, January 18).

By the release of the 2017 federal budget in March 2017, all provincial and territorial governments except for Manitoba had agreed in principle to accept the targeted federal transfer, and had even appeared 
to accept the federal government's condition that children and youth be a priority (Canada, 2017a). The budget also included new investments in social policy areas such as housing, and in mental health services for indigenous people, veterans, and corrections (Finance Canada, 2017).

Despite these historic achievements, the jurisdictional issues, stigma, and fiscal pressures that have sustained gaps in mental health policy for more than a century may still threaten meaningful progress. Unless additional private sector funds can be leveraged through social finance schemes, new federal investments in housing are only estimated to add 50,000 to 78,000 new units (approximately $\$ 140,000$ per unit x 78,000 units from a total investment of $\$ 10.9$ billion; Altus Group, 2015). Moreover, it is unclear how many of these will go toward people living with mental health problems. A recent report by the Wellesley Institute estimates a minimum requirement of 33,000 supportive housing units for people with mental illness and addiction in Ontario alone (Suttor, 2017). The impact of new federal mental health transfers could be watered down if provinces and territories insist on loose accountability provisions, much as with the 2003 and 2004 Health Accords. The federal contribution to mental health spending is likely now capped at $\$ 500$ million per year over and above whatever portion of the Canada Health Transfer and the Canada Social Transfer provinces and territories spend on mental health. A slower rate of increase in the overall CHT level will make it difficult for provincial and territorial governments to maintain current mental health funding levels, let alone

Table 1

\section{Closing the Mental Health Gap: Key Policy Options for Next Steps}

Provincial/Territorial contributions

Accountability mechanisms

Outcome measures

Direct vs. insured service delivery

Broad vs. narrow eligible expenses
New PT investments in mental health could come only from federal Health Accord transfers, or PTs could be required to match new federal investments or to at least ring-fence current levels of mental health spending.

An outcome framework could be negotiated, with accountability ranging from direct federal oversight, a revamped version of the Health Council of Canada, an existing arms-length organization such as the MHCC, or PT auditors general.

Reporting requirements could include clear indicators and performance targets, such as "providing mental health services to 500,000 more children and youth," or could be quite broad, such as "improving access to mental health services for Canadians."

A targeted transfer could be used to fund public services such as community mental health centres, or could be used to expand publically funded insurance of private practitioners, just as physician services are funded through provincial insurance plans.

A targeted transfer could be tied to a broad range of mental health activities, such as through support for the implementation of Canadian and PT strategies, or could be narrowly tied to specific population groups (such as children and youth or low income Canadians), activities (such as a particular program), or levels of evidence (such as randomized control trials). 
ensure that new federal funding goes toward increased spending on mental health. What is more, without matching by new investments from provincial and territorial governments, $84 \%$ ( $\$ 2.6$ billion annually) of the $\$ 3.1$ billion annual health spending gap will remain.

The details of actual funding agreements have yet to be made public, and may still be in development. Key policy options for next steps vary across several dimensions (see Table 1). These include provincial/ territorial contributions, accountability mechanisms, outcome measures, the insurance/financing model, and how tightly eligible expenses are tied to specific initiatives, population groups, or levels of evidence.

The Parliamentary Budget Office (2014) has found that dropping annual increases in federal health care transfers from $6 \%$ to $3 \%$ (a policy which was announced by the previous federal government and only increased to $3.5 \%$ in the current Health Accord), could jeopardize provinces' ability to maintain current levels of healthcare spending, and would result in a decline in the federal share of health funding to $11 \%$ by 2024. In this scenario it is hard to imagine provinces and territories being able to make new investments in mental health services; rather, service cuts might be necessary, something which has already begun in some jurisdictions under the current health transfer formula. A related issue is whether only federal transfers should be used to increase provincial and territorial rates of mental health spending, or whether the provinces and territories should match or contribute additional funding to improve their mental health systems. At a minimum, provinces and territories could be required to ring-fence their current levels of mental health spending in exchange for new federal funding.

Accountability mechanisms could range from direct federal oversight along the lines of the 1990s' Health Transition Fund, a revamped variation of the Health Council of Canada (which would hopefully address some of the lessons learned from the previous council), expanding the mandate of arms-length organizations such as the Mental Health Commission of Canada to include a monitoring function, or entrusting monitoring to provincial and territorial auditors general as per the recommendation from Out of the Shadows at Last (Canada, Senate Standing Committee on Social Affairs, Science and Technology, 2006, p. 45). It is worth noting that the Alberta Auditor General performed just such a function with its indictment of the provincial government's lack of implementation of its mental health and addictions strategy (Auditor General of Alberta, 2016). Bilateral agreements are likely to result in some variation in accountability mechanisms (Maslove, 2016 Jan. 8), in keeping with the premiers' endorsement of the principle of asymmetrical federalism (Council of the Federation, 2016). Not surprisingly, this principle was front-and-centre in the federal press release regarding the funding agreement with Quebec (Canada, 2017b). How much this asymmetry strengthens or weakens accountability remains to be seen.

Some kind of reporting framework is likely to be negotiated. The Trudeau government, with its commitment to "deliverology" (Curran, 2016), will likely be looking for a robust set of measureable outcomes and indicators. The 2017 federal budget included commitments for "improved accountability to Canadians through reporting on new ... mental health investments," and also provided examples of indicators regarding improved access to mental health services for children and youth (Finance Canada, 2017, pp. 156-157). However, provincial and territorial governments may be less keen to accept stringent targets or performance requirements, particularly as mental health is under their jurisdiction. 
The most likely insurance/financing model would seem to be direct public funding of services such as those provided by community mental health centres. In theory, demand-driven public health insurance could be expanded under provincial and territorial health insurance programs to cover a broader range of non-physician mental health services and providers (such as psychologists and social workers), backed up by explicit changes to the wording of the Canada Health Act. There are some possible scenarios that go in the direction of expanded insurance. Quebec has not only introduced a mixed model of public and employment-based insurance coverage to expand pharmaceutical coverage, but the Commissaire à la sante et au bien-être (2012) has also recommended expanded insurance coverage in the mental health sector and is currently undertaking a review of the basket of insured services (Commissaire à la sante et au bien-être, 2016; Institut national d'excellence en santé et en services sociaux, 2015). Meanwhile, in 2016 Ontario committed to introduce some kind of "structured psychotherapy program" (Ontario, 2017). While the approach has yet to be developed, psychotherapy services are often associated with insurance-based funding models. However, it seems highly unlikely that insurance-based approaches would garner enough support to get off the ground given concerns with maintaining control over expenditures. Likewise, there would appear to be little appetite for deviating from first-dollar health insurance coverage by tying federal mental health transfers to employment-based insurance (similar to the Canada Pension Plan) or to private insurance (along the lines of Obamacare).

Whatever the financing model adopted for the new targeted mental health transfer, eligible expenses could be broadly defined, or tied to specific initiatives, population groups, or levels of evidence. For example, in keeping with the federal interest in children and youth, eligible expenses could be as broad as anything that could potentially improve access to mental health services for people 25 and under. Alternatively, eligible expenses could be tied to scaling up a specific evidence-based approach such as the Australian headspace model (which is currently being piloted across Canada through the ACCESS Open Minds initiative; Graham Boeckh Foundation, n.d.). Further, criteria could be put in place that limit eligibility to those children and youth who currently face financial barriers in accessing mental health services because they are not covered by employment-based insurance (their own or their families) and cannot afford to pay out-of-pocket expenses. More flexible criteria may well be more acceptable to provincial and territorial governments, but could make it more difficult to ensure that funds would be spent on evidence-based approaches.

Over 50 years ago More for the Mind noted that no other field except leprosy has been subject to as much confusion, misdirection, and discrimination (Lurie \& Goldbloom, 2015). The new targeted federal mental health transfer is a major step toward overturning this historic failure in public policy. Nevertheless, the next steps will be critical. Leadership will be required from all levels of government and from the stakeholder community, to ensure accountability for the best possible use of these new public resources. What is more, to fully close the mental health gap, provincial and territorial governments will need to come up with at least another $\$ 2.5$ billion annually on top of the $\$ 600$ million federal investment. Developing provincial/territorial and national scorecards with public reporting to track the results of new investments will be critical, guided by national and provincial mental health indicator data. Sustained political will from policy makers at all levels of government, coordinated advocacy work by provincial, territorial, and national stakeholder groups, a marshalling of resources in pan-Canadian health organizations such as the Mental Health Commission of Canada and the Canadian Institute for Health Information, new research from the academic sector, and 
continued growth in public support will all be required if we are to build on the achievements of this new Health Accord and avoid more decades of neglect of our mental health systems. A good start has been made, but as the Beatles have suggested, it is a long and winding road.

\section{REFERENCES}

Altus Group. (2015). Construction guide. Toronto: Author. Retrieved from http://www.altusgroup.com/media/4099/ costguide_2015_web.pdf

Auditor General of Alberta. (2015). Report of the Auditor General of Alberta, July 2015. Retrieved from https://www. oag.ab.ca/webfiles/reports/OAG\%20Report\%20July\%202015.pdf

Banting, K. G., \& Corbett, S. M. (2002). Health policy and federalism: An introduction. In K. G. Banting \& S. M. Corbett (Eds.), Health policy and federalism: A comparative perspective on multi-level governance (pp. 1-38). Kingston, Ontario: Institute of Intergovernmental Relations, Queen's University.

Bartram, M. (2016). A targeted federal mental health transfer: Are prospects better under the Trudeau Liberals? In G. B. Doern \& C. Stoney (Eds.), How Ottawa Spends 2016-2017 (pp. 216-239). Ottawa: Carleton University.

Bégin, M. (1988). Medicare: Canada's right to health. Montréal: Optimum Publishers.

Canada. (2004). First ministers' meeting on the future of health care. Retrieved from http://healthycanadians.gc.ca/ health-system-systeme-sante/cards-cartes/collaboration/2004-meeting-racontre-eng.php

Canada. (2012). A consolidation of the Constitution Acts, 1867 to 1982. Ottawa: Justice Canada.

Canada. (2017a). Canada reaches health funding agreement with Ontario [news release]. Retrieved from https://www. canada.ca/en/health-canada/news/2017/03/canada_reaches_healthfundingagreementwithontario.html

Canada. (2017b). Canada reaches health funding agreement with Quebec [news release]. Retrieved from https://www. canada.ca/en/health-canada/news/2017/03/canada_reaches_healthfundingagreementwithquebec.html

Canada, House of Commons. (1957). Debates, Vol. 3.

Canada, House of Commons. (1967). Debates, Vol. 2.

Canada, House of Commons. (1968). Debates, Vol. 4.

Canada, House of Commons. (1982). Debates, Vol. 14.

Canada, Royal Commission on Health Services. (1964). Report: Volume 1. Ottawa: Author.

Canada, Standing Senate Committee on Social Affairs, Science and Technology. (2006). Out of the shadows at last: Transforming mental health, mental illness and addictions services in Canada. Ottawa: Government of Canada.

Canadian Alliance for Mental Illness and Mental Health. (2016). Mental health now! Advancing the mental health of Canadians: The federal role. Ottawa: Author. Retrieved from http://www.camimh.ca/wp-content/uploads/2017/01/ CAMIMH_MHN_EN_Final_Nov2016.pdf

Canadian Medical Association. (2016). New survey shows majority of Canadians support the federal government "topping up" health care funding of provinces and territories with older populations. Retrieved from https://www. cma.ca/En/Pages/new-survey-shows-majority-of-canadians-support-the-federal-government.aspx

CIHI. (2015). National health expenditures: How much does Canada spend on health care? Retrieved from https:// www.cihi.ca/en/spending-and-health-workforce/spending/national-health-expenditure-trends/nhex2015-topic1

CMHA. (2015). More for the mind mental health transition and innovation fund: A case for investment. Retrieved from http://www.cmha.ca/wp-content/uploads/2015/09/MH_Transition_Fund-Case_for_Investment-FINALupdated-1.pdf

Commissaire à la santé et au bien-être. (2012). Rapport d'appréciation de la performance du système de santé et de services sociaux 2012 [Sommaire]. Government of Quebec.

Commissaire à la santé et au bien-être. (2016). Basket of services: Public consultations 2016. Retrieved from http:// www.csbe.gouv.qc.ca/en/consultations/panier-de-services-2015.html

Council of the Federation. (2016). Health care sustainability: Communiqué. Retrieved from http://www.canadaspremiers.ca/phocadownload/newsroom_2016/health_care_sustainability_july22.pdf

Curran, R. (2016). Will “deliverology" work for the federal government? IRPP Policy Options. Retrieved from http:// policyoptions.irpp.org/magazines/april-2016/is-deliverology-right-for-canada/ 
Finance Canada. (2016). Federal support to provinces and territories. Retrieved from https://www.fin.gc.ca/fedprov/ mtp-eng.asp

Finance Canada. (2017). Building a strong middle class. Ottawa, ON: Author.

Galloway, G. (2017, January 3). Provinces seek to end health funding stand-off with Ottawa. The Globe and Mail. Retrieved from http://www.theglobeandmail.com/news/politics/provinces-renew-call-for-trudeau-meeting-on-health-funding/ article33477478/

Goldner, E. M. (2002). Sharing the learning: The Health Transition Fund synthesis series-mental health. Ottawa: Government of Canada.

Graham Boeckh Foundation. (n.d.). ACCESS Open Minds: Pan-Canadian integrated youth services intiative [website]. Retrieved from http://grahamboeckhfoundation.org/access-network/

Health Canada. (2007). Primary Health Transition Fund: Summary of initiatives. Retrieved from http://www.hc-sc. gc.ca/hcs-sss/pubs/prim/2007-initiatives/index-eng.php\#p3a3

Health Council of Canada. (2014). Better health, better care, better value for all: Refocusing health care reform in Canada. Toronto: Author.

Institut national d'excellence en santé et en services sociaux. (2015). Avis sur l'accès équitable aux services de psychothérapie. Retrieved from https://www.inesss.qc.ca/fileadmin/doc/INESSS/Rapports/PsychiatriePsychologie/ INESSS_FicheSynthese_Psychotherapie.pdf

Jacobs, P., Dewa, C., Lesage, A., Vasiliadis, H.-M., Escober, C., \& Mulvale, G. (2010). The cost of mental health and substance abuse services in Canada: A report to the Mental Health Commission of Canada. Edmonton, AB: Institute of Health Economics.

Kirkup, K. (2017, January 18). Holdout provinces urged to reach health funding deals to prioritize patients. Citynews. Retrieved from http://www.citynews.ca/2017/01/18/hold-out-provinces-urged-to-sign-health-agreements-formental-health-patients/

Lunn, S. (2016, June 23). Ottawa favours targeted health-care spending over increased transfer to provinces. $C B C$ News. Retrieved from http://www.cbc.ca/news/politics/philpott-health-accord-1.3649864

Lurie, S. (2005). Comparative mental health policy: Are there lessons to be learned? International Review of Psychiatry, $17,101$.

Lurie, S. (2014). Why can't Canada spend more on mental health? Health, 6, 684-690.

Lurie, S. \& Goldbloom, D. (2015). The legacy of More for the Mind. Canadian Journal of Community Mental Health, Special Issue 34(4), 7-30.

Maslove, A. (2016, January 8). Health care problems structural, not financial. Hill Times, 8. Retrieved from http:// www.longwoods.com/newsdetail/6690

MHCC. (2012). Changing directions, changing lives: The mental health strategy for Canada. Calgary, AB: Author.

MHCC. (2013). Turning the key: Assessing housing and related supports for persons living with mental health problems and illness. Calgary, AB: Author.

Mulvale, G., Abelson, J., \& Goering, P. (2007). Mental health service delivery in Ontario, Canada: How do policy legacies shape prospects for reform? Health Economics, Policy and Law, 2(4), 363-389.

OECD. (2014). Focus on health: Making mental health count. Paris: Author. Retrieved from https://www.oecd.org/els/ health-systems/Focus-on-Health-Making-Mental-Health-Count.pdf

OECD. (2016). Social expenditure-aggregated data. OECD.Stat. Retrieved from https://stats.oecd.org/Index. aspx?DataSetCode=SOCX AGG

Ontario. (2017). Ontario providing faster access to mental health services for thousands of people [news release]. Retrieved from https://news.ontario.ca/mohltc/en/2017/02/ontario-providing-faster-access-to-mental-healthservices-for-thousands-of-people.html

Ontario Ministry of Health. (1988). Building community support for people. Retrieved from http://ontario.cmha.ca/ files/2011/06/grahamreport.pdf

Ontario Ministry of Health. (1993). Putting people first. Retrieved from http://ontario.cmha.ca/files/2011/06/puttingpeoplefirst.pdf

Ouimet, H. R. (2014). Quebec and Canadian fiscal federalism: From Tremblay to Séguin and beyond. Canadian Journal of Political Science, 47(1), 47-69. 
Parliamentary Budget Office. (2014). 2014-2015 Federal transfers to provinces and territories. Retrieved from http:// www.pbo-dpb.gc.ca/web/default/files/files/files/TransferPayments EN.pdf

Prime Minister of Canada. (2015). Minister of Health mandate letter. Retrieved from http://pm.gc.ca/eng/ minister-health-mandate-letter

Statistics Canada. (2016). GDP Table 380-0064. Retrieved from http://www5.statcan.gc.ca/cansim/a26?lang=eng\&re trLang=eng\&id $=3800063 \& \&$ pattern $=\& s t B y V a l=1 \& p 1=1 \& p 2=31 \&$ tabMode $=$ dataTable \&csid

Stuart, H., Alboreda-Florez, J., \& Sartiorius, N. (2012). Paradigms lost: Fighting stigma and the lessons learned. Oxford: Oxford University Press.

Suttor, G. (2017). Supportive housing in Ontario: Estimating the need. Toronto, ON: Wellesley Institute. Retrieved from http://www.wellesleyinstitute.com/wp-content/uploads/2017/01/Supoortive-Housing-Estimating-the-Need.pdf

World Health Organization. (2011). Mental health atlas 2011. Geneva: Author. 